DOI: $10.19195 / 0867-7441.23 .5$

\title{
Katarzyna Kaczor
}

Uniwersytet Gdański

\section{SMOK to nie smok. Legendy polskie w XXI w.}

Słowa kluczowe: polska kultura popularna XXI w., polska literatura fantasy, legendy polskie, Robert M. Wegner, Tomasz Bagiński

Keywords: Polish popular culture of the 21 st century, Polish fantasy literature, Polish legends, Robert M. Wegner, Tomasz Bagiński

Kiedy w latach 80 . XX w. fantasy jako gatunek literatury popularnej przyjęła się na gruncie literatury polskiej, towarzyszyło temu dążenie do wykreowania jej rodzimej odmiany, której cechą dystynktywną byłaby kreacja świata przedstawionego opartego na motywach zaczerpniętych z mitologii i demonologii słowiańskiej $^{1}$. Jednakże nie zaowocowało ono utworami cieszącymi się uznaniem czytelników i krytyków². Pierwsze próby wykorzystywania ,żywiołu słowiańskiego" przez polskich fantastów zostały wyśmiane przez Andrzeja Sapkowskiego w szkicu Piróg, albo Nie ma złota w Szarych Górach ${ }^{3}$, co na blisko dekadę poskutkowa-

${ }^{1}$ Szerzej na ten temat zob. E. Żukowska, Typologia Piroga polskiego, czyli o fantasy słowiańskiej piętnaście lat później, „Czas Fantastyki” 2008, nr 3; K. Kaczor, Polacy nie gęsi i pisać fantasy też potrafia. O , Skarbach Stolinów” $i$ innych osobliwościach polskiej fantasy, [w:] Świat kuriozów. Od zadziwienia do fascynacji, red. K. Łeńska-Bąk, Opole 2016.

2 Przykładami utworów, które nie zyskały uznania czytelników i krytyków, są: Skarby Stolinów R.A. Ziemkiewicza (Krajowa Agencja Wydawnicza, Łódź 1990), „Saga o Kotołaku” K.T. Lewandowskiego, którą tworzą: Ksin (Orbita, Warszawa 1991), Różanooka (Victoria, Gdynia 1992), Wyprawa kotołaka (Copernicus, Warszawa 2003), Ksin drapieżca ([w:] idem, Trop kotołaka, SR, Warszawa 1998), Ksin koczownik (Warszawa 2006), Ludzkie ciepło („Fantastyka” 2007, nr 4 [wyd. specjalne] i Ksin na Bagnach Czasu (Copernicus, Warszawa 2017), oraz opowiadania A. Szrejtera: Król Pólnocy („Voyager” 1991, nr 1), Wieszczy („Fenix” 1991, nr 1) i Czerty Welesa („Fenix” 1992, nr 3; napisane wspólnie z M. Mosiewicz). Pozostawiam nazwy wydawnictw publikujących fantastykę, ponieważ jest to istotna kwestia dla moich rozważań.

${ }^{3}$ Zamieszczona w eseju A. Sapkowskiego satyra na polskie pirogi miała następujący kształt: „Nagle zrobiło się w naszej fantasy słowiańsko, przaśnie i kraśnie, jurnie, żurnie, podpiwkowo i lnianie. Swojsko. Zapachniało grodziszczem, wsią-ulicówką i puszczańskim wyrębem, powiało, Literatura i Kultura Popularna 23, 2017

(C) for this edition by CNS 
ło porzuceniem tego źródła inspiracji. Swoistymi świadectwami starań o wskrzeszenie Piastowskiej Słowiańszczyzny w polskiej literaturze fantastycznej XXI w. okazały się m.in. powieści: Kiedy Bóg zasypia Rafała Dębskiego ${ }^{4}$, Plagi tej ziemi Michała Krzywickiego ${ }^{5}$, Stowo i miecz Witolda Jabłońskiego ${ }^{6}$ oraz utwory Piotra Patykiewicza: Czorty, Odmieniec, Zly brzeg i Rajskie zorze ${ }^{7}$. W ciągu trzech dekad poza trojgiem twórców — Zbigniewem Nienackim, który w Dagome iudex ${ }^{8}$ zreinterpretował podania o początku polskiej państwowości, Sapkowskim, który w Granicy możliwości ${ }^{9}$ zdekonstruował podanie o Wandzie i legendę o Smoku Wawelskim, oraz Anną Brzezińską, która bohaterką cyklu opowiadań o Wilżyńskiej Dolinie uczyniła Babunię Jagódkę ${ }^{10}$ — polscy fantaści nie czerpali inspiracji

jak mawiają przyjaciele-Moskale — lietom, cwietom i - izwinitie — gawnom. Łup! Co tak huknęło? Czy to Bolko wbija słupy w Odrę? Czy to może Czcibor łupi Hodona i Zygfryda pod Cedynią? Czy też to może komar ze świętego dębu spadł?

Nie. To tylko nasza, rodzima, słowiańska fantasy.

Ni z tego, ni z owego zniknęły wampiry, pojawiły się wąpierze i strzygaje (sic!), zamiast elfów mamy bożęta i inne niebożęta, zamiast olbrzymów i trolli mamy stoliny. Zamiast czarodziejów i magów mamy wieszczych, wołchwów i żerców. Zaiste, brakuje jeno chlejców.

I co nam Conan, Ged Sparrowhawk, co nam Fellowship of the Ring. Mamy swojskich wojów, zwanych, ma się rozumieć, równie swojsko: Zbiróg, Piróg, Kociej, Pociej, Zagraj, Zabój, Przybój i Pozamiataj. I ruszyli owi Pirogowie od grodziszcza do grodziszcza, zygzakiem, rzecz jasna, ruszyli przez lasy, bory i welesy, przez tramy i chramy, skórznie, gopła, młaki i kotołaki, poprzez łany bujne i stepy, porosłe burzanem i chrzanem, przez święte gaje i ruczaje. [...]

Tych, którzy na Wielką Pirogiadę doczekać się nie mogą, uspokoję, streszczając dzieło. W Szarych Wierchach, dokąd wyprawi się Piróg i jego przaśna drużyna, złota nie ma i prawdopodobnie nigdy nie było. Ale niecny Strzygaj i wspierający go renegaci, źli zagraje Wolec i Stolec, zginą od sulicy w Pirogowej prawicy, przy czym chrobremu Pirogowi nawet weles z głowy nie spadnie. Skradzione Święte Żyto i Wieszcza Śmietana zostaną odzyskane i wrócą do chramu Swantewita, bo tam ich miejsce. Koniec” - A. Sapkowski, Piróg, albo Nie ma złota w Szarych Górach, „Nowa Fantastyka" 1993, nr 5, s. 71-72.

${ }^{4}$ R. Dębski, Kiedy Bóg zasypia, Fabryka Słów, Lublin 2007.

${ }^{5}$ M. Krzywicki, Plagi tej ziemi, Runa, Warszawa 2008.

6 W. Jabłoński, Słowo i miecz, SuperNOWA, Warszawa 2013.

7 P. Patykiewicz, Czorty, „Fenix” 1996, nr 3; idem, Odmieniec, SuperNOWA, Warszawa 2006; idem, Zty brzeg, SuperNOWA, Warszawa 2006; idem, Rajskie zorze, SuperNOWA, Warszawa 2007.

8 Powieść Dagome iudex Z. Nienackiego tworzą trzy tomy: Ja, Dago (Pojezierze, Olsztyn 1989), Ja, Dago Piastun (Pojezierze, Olsztyn 1989) oraz Ja, Dago Władca (Pojezierze, Olsztyn 1990).

9 A. Sapkowski, Granica możliwości, „Nowa Fantastyka” 1991, nr 9/10.

${ }^{10}$ Cykl A. Brzezińskiej „Wilżyńska Dolina” tworzą opowiadania (w kolejności publikacji): A kochat ja, że strach („Magia i Miecz” 1998, nr 10), Zaklęta księżniczka („Fenix” 1999, nr 5), Rzyć niewieścia wieloraka jest („Magia i Miecz” 1999, nr 7/8), Kot wiedźmy („Nieoficjalny Obiekt Literacki" 2001), tom Opowieści z Wilżyńskiej Doliny (Runa, Brok 2002 — pierwodruki utworów: Córki grabarza, Ballada, Grasanci z Kamiennego Lasu, Grzybobranie, Szczur i panna), Zbójnickie szczęście („Newsweek” 2003, nr 51/52), Marzenie Dracza („Fantasy” 2004, nr 2), Prawdziwy ksiąze (,Wysokie Obcasy” 27 maja 2006), Wiedźma z Wilżýnkiej Doliny (Runa, Warszawa 2010 — pierwodruki: Po prostu jeszcze jedno polowanie na smoka, Babie lato, Powrót władyki, Powrót kmiecia, Rusałka, Zagubione dzieci, Wiosna władyki) i dopełniający tom Płomień w kamieniu (opublikowany na stronie: http://www.runa.pl/wilzynska-dolina-plomien-w-kamieniu.html, dostęp: 30.11.2010).

Literatura i Kultura Popularna 23, 2017

(C) for this edition by CNS 
z rodzimych podań. W publikowanych utworach dawali wyraz raczej swoim zainteresowaniom chrześcijańską angelologią i demonologią („Zastępy Anielskie” Mai Lidii Kossakowskiej ${ }^{11}, 13$ anioł Anny Kańtoch ${ }^{12}$ ), mitologią skandynawską (cykl „Midgard” Marcina Mortki ${ }^{13}$, cykl „Loki” Jakuba Ćwieka ${ }^{14}$, Pan Lodowego Ogrodu Jarosława Grzędowicza ${ }^{15}$ ) i jakucką (Ruda sfora Kossakowskiej ${ }^{16}$ ) oraz opowieściami arturiańskimi (Maladie i Pani Jeziora Sapkowskiego ${ }^{17}$, Prawdziwa historia Morgan le Fay i rycerzy Okragłego Stołu Kwiatkowskiej ${ }^{18}$ ) i dziejami Robina z Sherwood (Prosto z Sherwood Kwiatkowskiej ${ }^{19}$ i cykl „Sherwood” Tomasza Pacyńskiego $\left.{ }^{20}\right)$.

Funkcjonujące w polskiej przestrzeni mitycznej, znane z lektury klechd i legend oraz z edukacji literackiej, a niewykorzystane przez polskich fantastów podania o Janie Twardowskim, Smoku Wawelskim, diabłach Borucie i Rokicie, bazyliszku oraz Piaście i Rzepisze zaistniały w nowych wersjach w polskiej kulturze popularnej za sprawą portalu aukcyjnego Allegro, który od 2015 r. finansuje two-

${ }^{11}$ Cykl M.L. Kossakowskiej „Zastępy Anielskie” tworzą Obrońcy Królestwa (Runa, Warszawa 2003), zawierający opowiadania (w kolejności publikacji): Sól na niebieskich pastwiskach („Fenix” 1999, nr 7), Kosz na śmierci („Fenix” 2000, nr 4), Beznogi tancerz („Fenix” 2000, nr 10), Wieża zapałek („Magia i Miecz” 2000, nr 4) oraz pierwodruki: Dopuszczalne straty, Smuga krwi, Światło w tunelu, Zobaczyć czerwień; Siewca Wiatru (Fabryka Słów, Lublin 2004), Żarna niebios (Fabryka Słów, Lublin 2008 - reedycja Obrońców Królestwa, uzupełniona o dwa nowe opowiadania: Gringo i Żarna niebios), Zbieracz Burz (Fabryka Słów, Lublin 2010) oraz Bramy Świattości (Fabryka Słów, Lublin 2017).

12 A. Kańtoch, 13 aniot, Fabryka Słów, Lublin 2007.

${ }^{13}$ Cykl „Midgard” M. Mortki tworzą Ostatnia saga (Runa, Warszawa 2003) i Świt po bitwie (Runa, Warszawa 2007), a także powiązana z nimi fabularnie Wojna runów (Runa, Warszawa 2004).

${ }^{14}$ Cykl „Loki” J. Ćwieka tworzą: Kłamca (Fabryka Słów, Lublin 2005 — opowiadania Aniot Stróż, Cicha noc, Cleaner, Egzorcysta, Galeria, Gtupiec na wzgórzu, Krew Baranka, Młot, wąż i skała, Przepowiednia, Samobójca), Kłamca 2. Bóg marnotrawny (Fabryka Słów, Lublin 2006 - opowiadania Bóg marnotrawny, Idźcie, jesteście posłani, Korona stworzenia, Odległość Anioła, Okazja, Studzy Metatrona), Troll i cmentarzysko niedźwiedzi (opowiadanie dołączone do gry Loki, prod. Focus Home Interactive, wyd. Cyanide Studio, Polska 2007), Kłamca 3. Ochłap sztandaru (Fabryka Słów, Lublin 2008), Kłamca 4. Kill'em All (Fabryka Słów, Lublin 2012), Kłamca. Viva l'arte (scen. J. Ćwiek, rys. D. Pochopień, kolor G. Nita, Sine Qua Non, Kraków 2012), Kłamca 2,5. Machinomachia (Sine Qua Non, Kraków 2014 — opowiadania Handlarz snów, Machinomachia, Swat) oraz Kłamca. Papież sztuk (Sine Qua Non, Kraków 2015).

15 Cztery tomy Pana Lodowego Ogrodu J. Grzędowicza wydała lubelska Fabryka Słów w latach: 2005, 2007, 2009 i 2012.

16 M.L. Kossakowska, Ruda sfora, Fabryka Słów, Lublin 2007.

17 A. Sapkowski, Maladie, „Nowa Fantastyka” 1992, nr 12; idem, Pani Jeziora, SuperNOWA, Warszawa 1999.

${ }^{18}$ K. Kwiatkowska, Prawdziwa historia Morgan le Fay i rycerzy Okragłego Stołu, Prószyński i S-ka, Warszawa 1998.

${ }^{19}$ K. Kwiatkowska, Prosto z Sherwood, Prószyński i S-ka, Warszawa 2000.

20 Nieukończoną (z powodu śmierci autora) trylogię „Sherwood” T. Pacyńskiego tworzą: Sherwood (Oficyna Wydawnicza „3,49”, Poznań 2001), Maskarada (Runa, Warszawa 2003), Wrota światów. Zła piosenka (Runa, Warszawa 2004) oraz Wrota światów: Garść popiołu (nieopublikowana).

Literatura i Kultura Popularna 23, 2017

(C) for this edition by CNS 
rzenie ich współczesnych reinterpretacji literackich i filmowych w ramach projektu „Legendy Polskie”. Ich przygotowanie i pozytywny odbiór - co zaowocowało nie tylko kolejnymi realizacjami z cyklu, lecz także ideą stworzenia całego uniwersum, rozumianego jako alternatywny świat, w którego realiach osadzone zostają fabuły różnych pod względem rodzajowym i gatunkowym tekstów kultury - inspirują do zbadania trzech kwestii. Pierwsza z nich dotyczy tego, w jaki sposób motywy zaczerpnięte z rodzimych klechd i legend są adaptowane i reinterpretowane w polskiej współczesnej kulturze popularnej, w dziełach nieadresowanych do odbiorcy dziecięcego. Druga: zastosowania (w kreacji świata przedstawionego) elementów o funkcji identyfikacyjnej i charakterze tożsamościowym - w celu podkreślenia polskiego charakteru tworzonego uniwersum. Trzecia zaś: próby wykorzystania (przy tejże kreacji) struktury opowieści transmedialnej21, co mimo braku rozmachu Matrixa (The Matrix, reż. Andrew Paul [ob. Lilly] Wachowski, Laurence [ob. Lana] Wachowski, Australia-USA 1999) czyni projekt zjawiskiem unikatowym na gruncie kultury polskiej.

W niniejszym artykule chciałabym poświęcić uwagę dwóm pierwszym zagadnieniom i zilustrować je analizą dwóch dzieł inicjujących cykl komplementarnymi reinterpretacjami legendy o Smoku Wawelskim - filmu $S M O K^{22}$ w reżyserii Tomasza Bagińskiego oraz opowiadania Milczenie owcy Roberta E. Wegnera ${ }^{23}$. Trzecia kwestia, ze względu na obszerność jej zakresu przekraczającego ramy tej pracy, pozostawiona zostanie do zbadania w późniejszym czasie.

\section{„Legendy Polskie" jako produkt kultury popularnej}

„Legendy Polskie” są projektem literacko-filmowo-muzycznym, realizowanym od 2015 r. na potrzeby kampanii wizerunkowej polskiego portalu aukcyjnego Allegro. Ma ona budować pozytywny odbiór marki wśród jej rodzimych użyt-

${ }^{21}$ Termin zaproponowany i zdefiniowany przez Henry’ego Jenkinsa w Kulturze konwergencji. Zderzeniu starych i nowych mediów (przeł. M. Bernatowicz, M. Filiciak, Warszawa 2007). Zob. ibidem, s. 95-96: „,[o]powieść transmedialna rozwija się na różnych platformach medialnych, a każdy tekst stanowi [w jej wypadku — K.K.] wyróżniającą się i ważną część całości. W idealnej formie opowiadania transmedialnego każde medium porusza się w sferze, w której jest najlepsze, tak aby historia mogła zostać wprowadzona w filmie, a rozwinięta przez telewizję, powieści i komiksy. [...] Każda forma dostępu do marki powinna być samowystarczalna, abyśmy nie musieli obejrzeć filmu po to, by cieszyć się grą, i odwrotnie. Każdy produkt jest punktem dostępu do marki jako całości. Czytanie poprzez różne media podtrzymuje taką głębię doświadczenia, która motywuje do większej konsumpcji”.

22 SMOK, reż. T. Bagiński, Polska 2015, http://www.youtube.com/watch?v=1J_Y12RqeLM (dostęp: 8.09.2016).

${ }^{23}$ R.M. Wegner, Milczenie owcy, [w:] R. Rak et al., Legendy polskie, Allegro, Warszawa 2015, s. 129-160, http://legendy.allegro.pl/wp-content/uploads/2016/09/legendy_polskie.pdf (dostęp: 8.11.2017).

Literatura i Kultura Popularna 23, 2017

(C) for this edition by CNS 
kowników przez podkreślanie jej polskiego rodowodu ${ }^{24}$ i kreowanie wysokiej jakości produktów, jakimi w tym wypadku są operujące fantastyką teksty kultury popularnej:

1. wydany w formie ebooka przez Powergraph tom opowiadań fantastycznych Legendy polskie ${ }^{25}$ — w którym znalazły się pierwodruki utworów: Jakuba Małeckiego Zwyczajny gigant (inspirowany Panem Twardowskim) ${ }^{26}$, Elżbiety Cherezińskiej Spójrz mi w oczy (inspirowane Bazyliszkiem) ${ }^{27}$, Radka Raka Kwiaty paproci ${ }^{28}$, Rafała Kosika Śnięci rycerze (inspirowane legendą O śpiacych rycerzach $)^{29}$, Wegnera Milczenie owcy (inspirowane Smokiem Wawelskim) i Łukasz Orbitowskiego Niewidzialne (inspirowane $\dot{Z} y w a$ woda) $)^{30}$ — oraz Wywiad $z$ Boruta Michała Cetnarowskiego i Orbitowskiego ${ }^{31}$;

2. seria wyreżyserowanych przez Tomasza Bagińskiego i zrealizowanych przez Platige Image krótkometrażowych filmów fabularnych: SMOK (premiera: 30 listopada 2015 r.), Twardowsky (15 grudnia 2015 r.) ${ }^{32}$, Twardowsky 2.0 (16 września 2016 r.) ${ }^{33}$, Operacja Bazyliszek (9 września 2016 r.) $)^{34}$ i Jaga (9 grudnia 2016 r.) $)^{35}$;

3. audiobook Wywiad z Boruta, w którego realizacji udział wzięli znany z Twardowsky'ego i Twardowsky'ego 2.0 Tomasz Drabek jako Boruta i Krystyna Janda jako Dziennikarka, co nieuchronnie przywołuje jej debiutancką rolę Agnieszki w Człowieku z marmuru Andrzeja Wajdy (Polska 1976);

4. teledyski do należących do kanonu polskiej muzyki rozrywkowej, a wykorzystanych na ścieżkach dźwiękowych wymienionych filmów coverów piosenek:

${ }^{24}$ Kwestia ta jest nie bez znaczenia w kontekście wzrastającej konkurencji w segmencie rynku zdominowanym przez portale aukcyjne, w którym głównymi konkurentami Allegro są amerykański Amazon i chiński AliExpress/Alibaba, rozszerzające swoją działalność na Polskę.

${ }^{25}$ R. Rak et al., op. cit.

26 J. Małecki, Zwyczajny gigant, [w:] R. Rak et al., op. cit.

27 E. Cherezińska, Spójrz mi w oczy, [w:] R. Rak et al., op. cit.

${ }^{28}$ R. Rak, Kwiaty paproci, [w:] idem et al., op. cit.

${ }^{29}$ R. Kosik, Śnięci rycerze, [w:] R. Rak et al., op. cit.

30 Ł. Orbitowski, Niewidzialne, [w:] R. Rak et al., op. cit.

${ }^{31}$ M. Cetnarowski, Ł. Orbitowski, Wywiad z Boruta, Allegro, Warszawa 2016, http://legendy. allegro.pl/wp-content/uploads/2016/09/wywiad_z_boruta.pdf (dostęp: 10.01.2017).

${ }^{32}$ Twardowsky, reż. T. Bagiński, Polska 2015, http://www.youtube.com/watch?v=hRdYz8cnOW4 (dostęp: 10.01.2017).

33 Twardowsky 2.0, reż. T. Bagiński, Polska 2016, http://www.youtube.com/watch?v=M-skpeuYmfE (dostęp: 10.01.2017).

34 Operacja Bazyliszek, reż. T. Bagiński, Polska 2016, http://www.youtube.com/watch?$\mathrm{v}=\mathrm{qS} 2 \mathrm{xTGLCu}-\mathrm{M}$ (dostęp: 10.01.2017).

${ }^{35} \mathrm{Jaga}$, reż. T. Bagiński, Polska 2016, http://www.youtube.com/watch?v=uKbuFYd468w (dostęp: 10.01.2017).

Literatura i Kultura Popularna 23, 2017

(C) for this edition by CNS 
Aleja gwiazd ${ }^{36}$, Mój jest ten kawałek podłogi ${ }^{37}$ i Jaskótka uwięziona ${ }^{38}$, rozwijające wątki: diablicy Lucy (Twardowsky i Twardowsky 2.0), policjanta Eugeniusza Bardachy (Operacja Bazyliszek) i Jagi (Jaga);

5. relacje filmowe prezentujące sam projekt oraz etapy produkcji zrealizowane przez Platige Image.

Wszystkie te utwory dostępne są - co podkreślają osoby zaangażowane w projekt — za darmo na stronie internetowej Legendy.allegro.pl oraz na kanale Allegro w serwisie YouTube. W ten sposób marka polskiego portalu aukcyjnego nie tylko jest kreowana na mecenasa kultury, lecz także wspiera ideę wolnego, ograniczonego tylko zasięgiem dystrybuującego medium, dostępu do kultury.

$\mathrm{W}$ odniesieniu do każdego $\mathrm{z}$ tekstów prezentowanych $\mathrm{w}$ ramach kampanii gwarantami jakości rozrywki oferowanej za ich pośrednictwem są zaangażowani w ich realizację, rozpoznawalni twórcy. Pisarze: Małecki (autor nominowanego do Zajdla Dżozefa ${ }^{39}$ ), Cherezińska (autorka historyczno-fantastycznych powieści o polskich Piastach ${ }^{40}$ ), Kosik (autor wielokrotnie nagrodzonej powieści Kamele$o n^{41}$ ), Orbitowski (laureat Paszportu „Polityki” i nominowany do nagrody „Nike” za powieść Inna dusza ${ }^{42}$ ), Wegner (najbardziej utytułowany w XXI w. polski autor fantasy $^{43}$ ); Bagiński (autor nagrodzonej Oscarem w 2003 r. Katedry, Polska 2002, oraz twórca Animowanej historii Polski, reklamującej Polskę na wystawie EXPO w 2010 r. w Szanghaju ${ }^{44}$, filmu Grunwald. Walka 600-lecia ${ }^{45}$, filmowych prologów

${ }^{36}$ Matheo, A. Karwan, Aleja Gwiazd. Cover, reż. M. Sakowski, Polska 2016, http://www. youtube.com/watch?v=fMU2Y4F0BDw (dostęp: 10.01.2017).

${ }^{37}$ Matheo, A. Donarski, Mój jest ten kawałek podłogi. Cover, reż. K. Kądziela, Polska 2016, http://www.youtube.com/watch?v=Zw0BnTi_XJc (dostęp: 10.01.2017).

38 A. Valkov, G. Tarasiuk, Jaskótka uwięziona. Cover, reż. K. Czekaj, Polska 2016, http://www. youtube.com/watch? $=$ qdCmSt4798g (dostęp: 10.01.2017).

39 J. Małecki, Dżozef, W.A.B., Warszawa 2011.

40 E. Cherezińska, Korona śniegu i krwi, Zysk i S-ka, Poznań 2012; eadem, Niewidzialna korona, Zysk i S-ka, Poznań 2014; eadem, Harda, Zysk i S-ka, Poznań 2016; eadem, Królowa, Zysk i S-ka, Poznań 2016; eadem, Płomienna korona, Zysk i S-ka, Poznań 2017.

${ }^{41}$ R. Kosik, Kameleon, Powergraph, Warszawa 2008.

42 Ł. Orbitowski, Inna dusza, Od Deski do Deski, Warszawa 2015.

${ }^{43}$ R.M. Wegner jest pięciokrotnym laureatem Nagrody Fandomu Polskiego im. J.A. Zajdla - za utwory: Wszyscy jesteśmy Meekhańczykami (2009), Jeszcze jeden bohater i Niebo ze stali (2012), Pamięć wszystkich słów. Opowieści z meekhańskiego pogranicza i Milczenie owcy (2015); oraz dwukrotnym laureatem Sfinksa i Srebrnego Wyróżnienia przyznawanego przez jury Nagrody Literackiej im. J. Żuławskiego za Niebo ze stali.

${ }^{4}$ Animowana historia Polski, reż. T. Bagiński, Polska 2010, http://www.youtube.com/ watch? $=\mathrm{cEQzgqFxpJE}$ (dostęp: 10.01.2017).

45 Grunwald. Walka 600-lecia, reż. T. Bagiński, Polska 2010, http://www.youtube.com/ watch? $\mathrm{v}=\mathrm{gVCuNH6uAMU}$ (dostęp: 9.11.2017).

Literatura i Kultura Popularna 23, 2017

(C) for this edition by CNS 
do wszystkich trzech gier Wiedźmin ${ }^{46}$ i krótkometrażowej Ambicji ${ }^{47}$ — filmu fabularnego promującego misję sondy Rosetta); a także ikony polskiego aktorstwa: wspomniana już Janda oraz odtwórca postaci Lecha Wałęsy w filmie Andrzeja Wajdy (Wałęsa. Człowiek z nadziei, Polska 2013) — Robert Więckiewicz.

Wskazane w nazwie projektu źródło inspiracji i osoby zaangażowanych artystów podkreślają jego rodzimy — w znaczeniu ,polski” — charakter oraz implikują, że wnosi on do kultury popularnej nową jakość, oryginalną właśnie ze względu na to źródło inspiracji. Novum jest też wspomniany sposób dystrybucji „Legend Polskich" za pośrednictwem ogólnie dostępnego Internetu, co umożliwiło efektywne dotarcie do blisko 40 tys. czytelników, 25 tys. słuchaczy i 4 mln widzów ${ }^{48}$; jednocześnie warto wskazać, że filmy opatrzono angielskim napisami, poszerzając tym samym grupę potencjalnych odbiorców.

\section{Już nie Smok Wawelski, lecz SMOK}

Pierwszą odsłoną projektu, opatrzonego hasłem: „Legenda o odwadze, sile, ambicji, empatii, sprycie, dumie. O nas" ${ }^{\prime 9}$, były: wydany przez Powergraph i sygnowany przez Allegro tom opowiadań Legendy polskie oraz pierwszy z krótkometrażowych filmów fabularnych zrealizowanych na zlecenie portalu przez studio Platige Image. Spośród utworów inicjujących projekt popularność wśród odbiorców i ich uznanie zdobyły dwie komplementarne wobec siebie, utrzymane w konwencji science fiction, reinterpretacje legendy o Smoku Wawelskim: nagrodzone w 2016 r. Zajdlem opowiadanie Milczenie owcy Wegnera i wyreżyserowany przez Bagińskiego film SMOK.

Podstawą reinterpretacji obu tekstów jest wersja legendy, sparafrazowana przez Wegnera w Milczeniu owcy jako jedna z opowieści z Lasu bajek, wpisanego w strukturę tego opowiadania:

Wirtualny świat już się przesuwał, zabierając grupę na skraj lasu. Na wzgórzu, odległym o kilkaset metrów, pysznił się zamek, ozdobiony jak należy zębatymi blankami i strzelistymi wieżyczkami, a u jego podnóża, na łące, hasało stado śnieżnobiałych owieczek.

Jedna zastrzygła uszami, uniosła łebek i wlepiła wzrok w grupkę dzieci. [...]

W wirtualnej krainie smok siał terror i strach. Latał, porywał rogaciznę i nierogaciznę oraz, ziejąc ogniem, podpalał to i owo. Wszystko oczywiście zgodnie z wytycznymi o bajkach

46 Wiedźmin, prod. CD Projekt RED, wyd. Atari, Polska 2007; Wiedźmin 2. Zabójcy królów, prod. CD Projekt RED, wyd. CD Projekt, Polska 2011; Wiedźmin 3. Dziki Gon, prod. CD Projekt RED, wyd. CD Projekt, Polska 2015.

47 Ambition, reż. T. Bagiński, Irlandia-Islandia-Polska 2014, http://www.ambitionfilm.com (dostęp: 10.01.2017).

48 Odnotowane na stronach prezentujących projekt liczby pobrań i odtworzeń odpowiednio: Legend polskich, Wywiadu z Boruta i SMOK-a na kanale Allegro na portalu YouTube na dzień 16 grudnia $2016 \mathrm{r}$.

${ }^{49}$ Legendy Polskie. Kulisy projektu, http://www.youtube.com/watch?v=yWW5nrhlk00\&spfreload=1 (dostęp: 10.01.2017). 
dla dzieci w wieku od czterech do siedmiu lat. Żadnej krwi, żadnej bezpośredniej przemocy, porywane w powietrze owieczki robiły głupie i zaskoczone miny, po czym znikały w smoczej jaskini, a podpalone budynki gaszono jednym wiadrem wody. [...]

Dzieciaki chłoną bajkę tak, jak tylko pięciolatki potrafią. Dosłownie z otwartymi buziami. Oglądały ją już przynajmniej kilkanaście razy, ale nadal nie wyglądają na znudzone. Może dlatego, że Las Bajek za każdym razem nieco modyfikuje historię, smok był już zielony, czerwony, brązowy, a teraz jest czarny, owce czasem porażały bielą runa, kiedy indziej były żółte, szare albo niebieskie, natomiast rycerze pędzący w stronę bestii raz galopowali konno, innym razem strzelali do niej z wielkich machin, a niekiedy po prostu biegli do ataku, wymachując karykaturalnie wielkimi mieczami. Tak jak teraz. [...]

W baśniowej krainie oddział rycerzy dopadł właśnie smoka. Na chwilę, zgodnie z ustawą o ograniczeniu przemocy, wszystko przesłonił tuman kurzu. [...]

W Krainie Bajek smutny król siedział na tronie i dumał. Kilku osmolonych rycerzy w pogniecionych zbrojach opierało się o ściany, a kilka dam dworu cicho rozpaczało. Nagle władca rozpogodził się, skinął na skrybę i zaczął z zapałem coś dyktować. W następnej scenie herold ogłaszał nowinę mieszkańcom grodu, młody pasterz drapał się zaś z zafrasowaniem po głowie.

Potem z zapałem zszywał owczą skórę i wypełniał ją straszliwym wkładem, w bajce ukazanym jako różne paskudztwa, takie jak pająki i brudne skarpetki. Dzięki Bogu, jeszcze żadne dziecko nigdy nie zapytało, jak wcześniej ściągnął skórę z owieczki. [...]

Tymczasem przed bajkowym zamkiem wypchana owca stoi i stara się wyglądać na żywą. Smok podlatuje, krąży, waha się.

Dzieci w napięciu zaciskają dłonie w piąstki. [...]

Smok połyka wreszcie wypchaną owieczkę, oblizuje się, beka. Nagle stawia oczy w słup, kaszle, łapie [się - K.K.] za gardło i, ciągnąc za sobą wzdęte brzuszysko, pełznie w stronę rzeki. Po chwili nad brzegiem dochodzi do malowniczej eksplozji.

Dzieci wiwatują.

Koniec bajki ${ }^{50}$.

Wybrana za podstawę dwudziestopierwszowiecznej reinterpretacji wersja legendy o Smoku Wawelskim została opublikowana w 1597 r. przez Joachima Bielskiego w Kronice polskiej Marcina Bielskiego nowo przez syna jego wydanej ${ }^{51}$. Według tej wersji pomysłodawcą zgładzenia smoka za pomocą nadzianej siarką skóry cielaka był szewczyk Skuba ${ }^{52}$. Przytaczając legendę — jak wykazywał Aleksander Brückner w Encyklopedii staropolskiej - w wariancie pierwotnym, funkcjonującym w tradycji ustnej, kronikarz z XVI w. pominął dokonane trzy wieki wcześniej przez Wincentego Kadłubka „oszlachcenie”53, którego przejawem było uczynienie pogromcami smoka synów Grakcha ${ }^{54}$, i zainicjował zachodzący w kolejnych wersjach legendy proces minimalizowania roli Kraka na rzecz doceniania dzielnego szewczyka. I to właśnie ten wariant funkcjonuje jako kanoniczny, na co wskazują jego liczne opracowania i utwory przywołujące postać

${ }^{50}$ R.M. Wegner, op. cit., s. 131-159.

51 Zob. A. Brückner, Krak, [hasło w:] idem, Encyklopedia staropolska, Warszawa 1939, t. 1, s. 699; zob. też: M. Plezia, Legenda o smoku wawelskim, „Rocznik Krakowski” 1971, t. 42, s. 24. Wzmiankowana Kronika ... była nową wersją Kroniki wszystkiego świata (1551) Marcina Bielskiego.

52 A. Brückner, op. cit.

53 Ibidem.

54 A. Brückner, op. cit.; M. Plezia, op. cit., s. 23.

Literatura i Kultura Popularna 23, 2017

(C) for this edition by CNS 
Smoka Wawelskiego, pojawiające się na gruncie literatury polskiej od XIX w., pozbawiające krakowską bestię grozy ${ }^{55}$.

Miejscem akcji Milczenia owcy jest ,świat niedalekiej przyszłości”, pomija się tu więc dokładniejszą lokalizację. Precyzują ją wszakże autorzy $S M O K-a$, jednoznacznie czyniąc nią „Kraków w niedalekiej przyszłości”. Jego genius loci w filmie przywoływany jest przez ikoniczne obrazy Rynku z Sukiennicami i wieżami Kościoła Mariackiego, osobę Jerzego Stuhra odtwarzającego postać hejnalisty i ilustrujący rajdy SMOK-a — oraz kreujący Kraków na miejsce przerażające - cover Cichoszy Grzegorza Turnaua ${ }^{56}$ w wykonaniu Krzysztofa Zalewskiego. Miasto, będące duchową stolicą Polski, terroryzuje napastnik latający podniebnym krążownikiem „SMOK” i porywający młode dziewczęta. Jego pogromcą zostaje pasjonujący się robotyką nastolatek, Janek Szewczyk, który w celu zniszczenia „SMOK-a” konstruuje androida mającego postać atrakcyjnej młodej kobiety. Przynęta zwabia agresora i znalazłszy się we wnętrzu powietrznego statku, czyli w trzewiach potwora, wybucha, unicestwiając go.

Dokonane przez współczesnych twórców filmu przekształcenia treści legendy o Smoku Wawelskim, przy zachowaniu jej oryginalnego schematu fabularnego i symboliki postaci, ilustruje wykres:

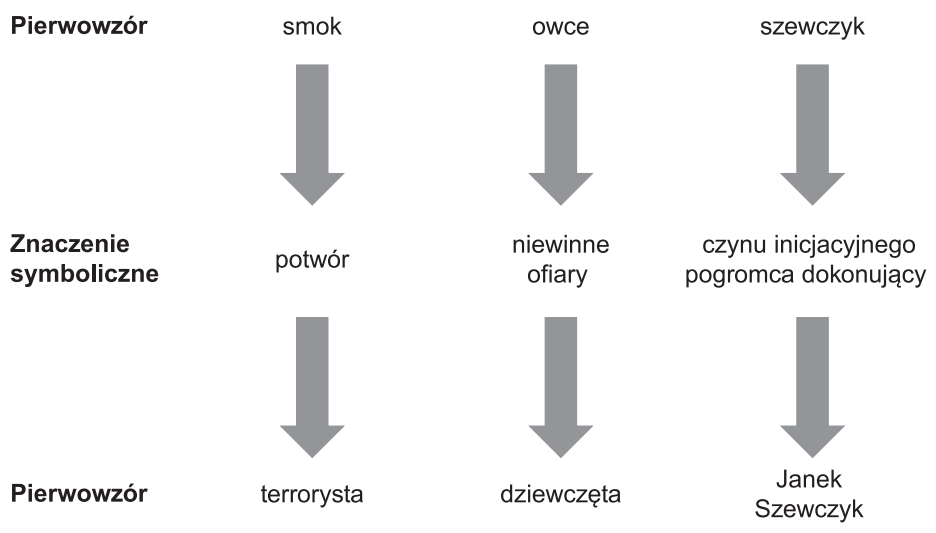

Wykres 1. Reinterpretacja schematu fabularnego legendy o Smoku Wawelskim

Źródło: opracowanie własne.

55 Szerzej o tym w zbiorze zob. G. Skotnicka, O smoku wawelskim i Kraku w nierozerwalnym duecie, [w:] Kraków mityczny. Motywy, watki, obrazy w utworach dla dzieci i młodzieży, red. A. Baluch, M. Chrobak, M. Rogoż, Kraków 2009; V. Wróblewska, Smok wawelski i inne smoki w polskiej literaturze dla dzieci, [w:] Kraków mityczny...; J. Ługowska, Dzieje smoka wawelskiego przez Stanisława Pagaczewskiego opowiedziane, [w:] Kraków mityczny...; K. Kwaśniewicz, Smok jaki jest, każdy widzi. Smok wawelski w ilustracji dziecięcej (rekonesans badawczy), [w:] Kraków mityczny...

${ }^{56}$ M. Macuk,K.Zalewski, Cichosza. Cover,http://legendy.allegro.pl/wp-content/uploads/2016/08/ Allegro_Cichosza_Zalewski_Legendy_Polskie.mp3 (dostęp: 10.11.2017).

Literatura i Kultura Popularna 23, 2017

(C) for this edition by CNS 
Różnice między dwiema współczesnymi reinterpretacjami legendy o Smoku Wawelskim wskazane są w ich tytułach — Milczenie owcy i SMOK. Opowiadanie Wegnera prezentuje bowiem wydarzenia, które zainspirowały legendę, z perspektywy „owcy” - androida będącego zdalnie sterowaną, mobilną bombą. Ale co jest właściwe współczesnym opowieściom o humanoidalnych robotach, tak samo jak bohaterowie Łowcy androidów (Blade Runner, reż. R. Scott, Hongkong-USA-Wielka Brytania 1982) i A.I. Sztucznej inteligencji (Artifical Intelligence: AI, reż. S. Spielberg, USA 2001), ma on tożsamość manifestującą się przez świadomość własnej przeszłości oraz etapów przekonstruowywania i poprzez pragnienie życia. Zostało to zaprezentowane $\mathrm{w}$ formie obcego konwencji science fiction, a dystynktywnego dla prozy psychologicznej, strumienia świadomości, co wskazuje, że literackim źródłem inspiracji Wegnera była powieść Philipa K. Dicka $C z y$ androidy marzq o elektrycznych owcach? (Do Androids Dream of Electric Sheep?, 1968, pol. 1995). Inni uczestnicy zdarzeń: pilot „SMOK-a”, jego ofiary, terroryzowana społeczność i Janek pozostają w tle, pojawiając się we wspomnieniach byłej nauczycielki chłopca, która obecnie uczy przedszkolaków zafascynowanych przedstawianą historią.

Twórcy filmu swoją uwagę koncentrują na smoku w znaczeniu metaforycznym — personifikacji najsilniejszych narodowych lęków Polaków. Jest nią były żołnierz Armii Czerwonej Adolf Kamczatkow, który nosi imię wodza III Rzeszy i nazwisko podkreślające jego wschodnioazjatyckie pochodzenie. Reprezentując wyobrażenie radzieckich sołdatów niszczących wyzwalaną Polskę, nie tylko porywa młode kobiety, ekscytuje się ich zapachem i więzi je w opuszczonym wieżowcu, grając im na bałałajce, lecz także ostrzeliwuje wieżę kościoła Mariackiego, z której rozbrzmiewa hejnał, co czyni tego antagonistę barbarzyńcą dokonującym brutalnego najazdu. Analogicznie jak w Milczeniu owcy, bohaterów $S M O K$ - $a$ ukazano zgodnie z aktualnymi trendami popkulturowymi. Twórcy filmu zaprezentowali potwora w sposób podkreślający jego groteskowość. Fetyszyzm Kamczatkowa służy z kolei zaakcentowaniu jego „dzikości” i „zwierzęcości”. Natomiast uczynienie jedną z ofiar SMOK-a przyjaciółki Janka wprowadza do reinterpretacji znanej wszystkim legendy — w celu uaktualnienia opowieści, zgodnie ze współczesnym paradygmatem konstruowania fabuł, których odbiorcami są nastolatki - motyw osobistej motywacji misji bohatera, co podkreśla jej charakter inicjacyjny.

Zreinterpretowanie legendy w konwencji science fiction skutkuje zmianą realiów i wykorzystaniem rekwizytorium właściwego tej konwencji, tworzonego głównie przez zaawansowane technologicznie urządzenia. W filmie są to panel kontroli dostępu do wieży Mariackiej i myśliwce próbujące strącić lecącego SMOK-a, w opowiadaniu — powszechnie używane gogle umożliwiające przedszkolakom przeżywanie przygód w wirtualnym świecie; w obu dziełach zaś — android mają- 
cy zdolność samoprzebudowy (niczym terminator T-1000 57 ). Dla Wegnera przypisana robotowi umiejętność transformacji staje się pretekstem do zaprezentowania jego rodzącej się emocjonalności, a dla ekipy Bagińskiego - płynności jego przemiany z atrakcyjnej dziewczyny w mechaniczną panterę, co jest efektem tworzącym wizualną spektakularność filmowego widowiska. Wybrana konwencja pozwoliła też na pokazanie, że w epoce Internetu i mediów społecznościowych zagrażający społeczności złoczyńca również może stać się obiektem deklaracji miłosnych. Przekształcenie figur potwora, jego ofiary i pogromcy zdaje się nie skutkować reinterpretacją ich znaczeń symbolicznych. Mimo tego, dzięki przywróceniu pozytywnego bohatera, historia o pokonującym SMOK-a kreatywnym Janku Szewczyku, którego motywacje może zrozumieć każdy nastolatek, ocala polską legendę o odwadze i sprycie oraz — jak wskazuje Gertruda Skotnicka — „o przedkładaniu dobra ogółu nad dobro własne" ${ }^{58}$. Przywraca więc tę cechę opowieści, która ćwierć wieku wcześniej została zniszczona przez Sapkowskiego w Granicy możliwości — jej walor przedstawiania wartości uniwersalnych.

\section{Zakończenie}

Mario Praz w Mnemosyne. Rzeczy o powinowactwie literatury i sztuk plastycznych napisał, że

w naśladowaniu dzieła sztuki krystalizuje się interpretacja i smak epoki, w jakiej owo naśladownictwo jest dokonywane; z biegiem lat drugi z tych elementów [...] przybiera na sile i staje się coraz wyraźniej dostrzegalny; i jak przy zwłokach Mr Hyde’a, w filmie nakręconym według znanego opowiadania Stevensona, z wolna pojawia się profil dr. Jekylla, tak w podrobionym dziele spod przebrania wyłania się powoli profil fałszerza ${ }^{59}$.

Niewątpliwie tak też jest w przypadku Granicy możliwości, SMOK-a i Milczenia owcy. Ale dostrzegając różnicę intencji, z jakimi autorzy wymienionych interpretacji traktują tekst poznanej w dzieciństwie legendy, należy również stwierdzić, że ich reinterpretacje odzwierciedlają: (1) dominujący sposób percepcji rodzimego dziedzictwa kulturowego w danym czasie; (2) funkcjonującą hierarchię postaw; (3) zdolności jednostki do wpływania na kształt świata. Dokonana przez Sapkowskiego dekonstrukcja legendy o Smoku Wawelskim oraz obserwowane w polskiej literaturze fantasy odrzucenie inspiracji rodzimymi legendami na rzecz mitologii skandynawskiej i literatury arturiańskiej wskazywały na dominującą w polskiej kulturze popularnej tendencję do odrzucania własnej tożsamości — jako prowincjonalnej — na rzecz unifikacji właściwej procesom globalizacyjnym; natomiast

${ }^{57}$ Bohater filmu Terminator 2: Dzień sądu (Terminator 2: Judgment Day, reż. J. Cameron, Francja-USA 1991).

58 G. Skotnicka, op. cit., s. 122.

${ }^{59}$ M. Praz, Mnemosyne. Rzecz o powinowactwie literatury i sztuk plastycznych, przeł. W. Jekiel, Warszawa 1981, s. 39. 
„Legendy Polskie” świadczą o przełamaniu tego trendu, o traktowaniu lokalności jako kryterium różnicującego, w kulturze nisz waloryzowanego pozytywnie. Wyrazem tego jest nasycanie lokalnością wszystkich poziomów kreowanych opowieści: świata przedstawionego, języka, wywoływanych skojarzeń i implikowanych sensów, ze względu na ich rozpoznawalność mających charakter idiomów.

O ile dekady przełomu XX i XXI w. cechowało kwestionowanie prymatu intelektu na rzecz siły oraz odrzucenia działania indywidualnego na rzecz funkcjonowania w korporacyjnej grupie - co reprezentuje uczestnicząca w polowaniu na Villentretenmertha drużyna krasnali, wiedziona przez Yarpena Zigrina i nieprzebierająca w środkach w celu zdobycia skarbu - o tyle w drugiej dekadzie obecnego wieku wzorzec ten został odrzucony na rzecz indywidualizmu i uznawania pasji i kreatywności za przymioty umożliwiające osiągnięcie sukcesu. Skutkuje to interpretowaniem przypisanego szewczykowi Skubie sprytu jako inwencji, która umożliwia Jankowi Szewczykowi unicestwienie SMOK-a. Takie ujęcie poświadcza też trzecią ze zmian, jaką jest odrzucenie imperatywu działań w skali globalnej. Towarzyszy temu odzyskanie wiary w zdolność jednostki do kształtowania własnego losu i przez to do wpływania — w skali lokalnej — na otaczającą rzeczywistość.

\section{DRAGON is not a dragon. Polish legends in the 21 st century}

\section{Summary}

The subject of the article is the presentation of the project "Legends of Poland", indicating the reinterpretation strategies used by its creators. The subject of the analysis are the works by Robert M. Wegner and Tomasz Baginski - the story Milczenie owcy (The Silence of a Lamb) and its film adaptation SMOK (DRAGON). Their authors reinterpreted the most famous Polish legend about the Wawel dragon in a science fiction convention, thus pointing to the potential of famous stories that can be used to create whole universes. 